U.S. GEOLOGICAL SURVEY CIRCULAR 1046

The Alaska Mineral Resource Assessment Program: Background Information to Accompany Folio of Geologic and Resource Maps of the Ugashik, Bristol Bay, and Western Part of Karluk Quadrangles, Alaska 


\section{AVAILABILITY OF BOOKS AND MAPS OF THE U.S. GEOLOGICAL SIJRVEY}

Instructions on ordering publications of the U.S. Geological Survey, along with prices of the last offerings, are given in the current-year issues of the monthly catalog "New Publications of the U.S. Geological Survey." Prices of available U.S. Geological Survey publications released prior to the current year are listed in the most recent annual "Price and Availability List." Publications that are listed in various U.S. Geological Survey catalogs (see back inside cover) but not listed in the most recent an"ual "Price and Availability List" are no longer available.

Prices of reports released to the open files are given in the listing "U.S. Geological Survey Open-File Reports," rndated monthly, which is for sale in microfiche from the U.S. Geological Survey, Books and Open-File Reports Section, Federnl Center, Box 25425, Denver, CO 80225. Reports released through the NTIS may be obtained by writing to the National Technical Information Service, U.S. Department of Commerce, Springfield, VA 22161; please include NTIS report number with inquiry.

Order U.S. Geological Survey publications by mail or over the counter from the offices given below.

\section{BY MAIL}

\section{Books}

Professional Papers, Bulletins, Water-Supply Papers, Techniques of Water-Resources Investigations, Circulars, publications of general interest (such as leaflets, pamphlets, booklets), single copies of Earthquakes \& Volcanoes, Preliminary Determination of Epicenters, and some miscellaneous reports, including some of the foregoing series that have gone out of print at the Superintendent of Documents, are obtainable by mail from

\section{U.S. Geological Survey, Books and Open-File Reports Federal Center, Box 25425 Denver, CO 80225}

Subscriptions to periodicals (Earthquakes \& Volcanoes and Preliminary Determination of Epicenters) can be obtained ONLY from the

\section{Superintendent of Documents Government Printing Omice Washington, D.C. 20402}

(Check or money order must be payable to Superintendent of Documents.)

\section{Maps}

For maps, address mail orders to

$$
\begin{aligned}
& \text { U.S. Geological Survey, Map Distribution } \\
& \text { Federal Center, Box } 25286 \\
& \text { Denver, CO } 80225
\end{aligned}
$$

Residents of Alaska may order maps from

$$
\begin{gathered}
\text { Alaska Distribution Section, U.S. Geological Survey, } \\
\text { New Federal Building - Box } 12 \\
101 \text { Twelinth Ave., Fairbanks, AK } 99701
\end{gathered}
$$

\section{OVER THE COUNTER}

\section{Books}

Books of the U.S. Geological Survey are available over the counter at the following Geological Survey Public Inqriries Offices, all of which are authorized agents of the Superintendent c $f$ Documents:

- WASHINGTON, D.C.--Main Interior Bldg., 2610 corridor, 18th and C Sts., NW.

- DENVER, Colorado--Federal Bldg., Rm. 169, 1961 Stout St.

- LOS ANGELES; California-Federal Bldg., Rr. 7638, 300 N. Los Angeles St.

- MENLO PARK, Callfornia--Bldg. 3 (Stop 533) Rm. 3128, 345 Middlefield Rd.

- RESTON, Virginia--503 National Center, Rm. 1C402, 12201 Sunrise Valley Dr.

- SALT LAKE CITY, Utah--Federal Bldg., Rm. 8105, 125 South State St.

- SAN FRANCISCO, Callifornia--Customhouse, Rm. 504, 555 Battery St.

- SPOKANE, Washington--U.S. Courthouse, Rn. 678, West 920 Riverside Ave..

- ANCHORAGE, Alaska-Rm. 101, 4230 University Dr.

- ANCHORAGE, Alaska-Federal Bldg, Rm. E-146, 701 C St.

\section{Maps}

Maps may be purchased over the counter at th: U.S. Geological Survey offices where books are sold (all addresses in above list) and at the following Geological Survey offices:

- ROLLA, Missouri--1400 Independence Rd.

- DENVER, Colorado--Map Distribution, Bldg. 810, Federal Center

- FAIRBANKS, Alaska--New Federal Bldg., 101 Twelfth Ave. 
The Alaska Mineral Resource Assessment Program: Background Information to Accompany Folio of Geologic and Resource Maps of the Ugashik, Bristol Bay, and Western Part of Karluk Quadrangles, Alaska

By R.L. DETTERMAN, J.E. CASE, S.E. CHURCH, J.G. FRISKEN, F.H. WILSON, and M.E. YOUNT 
DEPARTMENT OF THE INTERIOR

MANUEL LUJAN, JR., Secretary

U.S. GEOLOGICAL SURVEY

Dallas L. Peck, Director

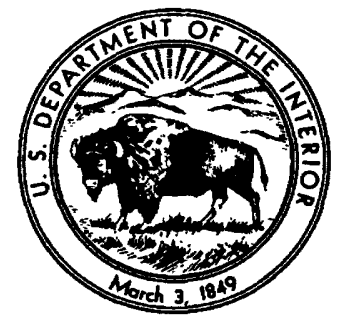

Any use of trade, product, or firm names in this publication is for descriptive purposes only and does not imply endorsement by the U.S. Government

Library of Congress Cataloging-in-Publication Data

The Alaska Mineral Resource Assessment Program.

(U.S. Geological Survey circular ; 1046)

Includes bibliographical references (p. ).

Supt. of Docs. no.: I 19.4/2:1046

1. Geology-Alaska-Alaska Peninsula. 2. Mines and mineral resources-

Alaska-Alaska Peninsula. 3. Alaska Mineral Resource Assessment Program.

I. Detterman, Robert L. II. Series.

QE84.A34A43 1990

$553^{\prime} .09798$

90-3121 


\section{CONTENTS}

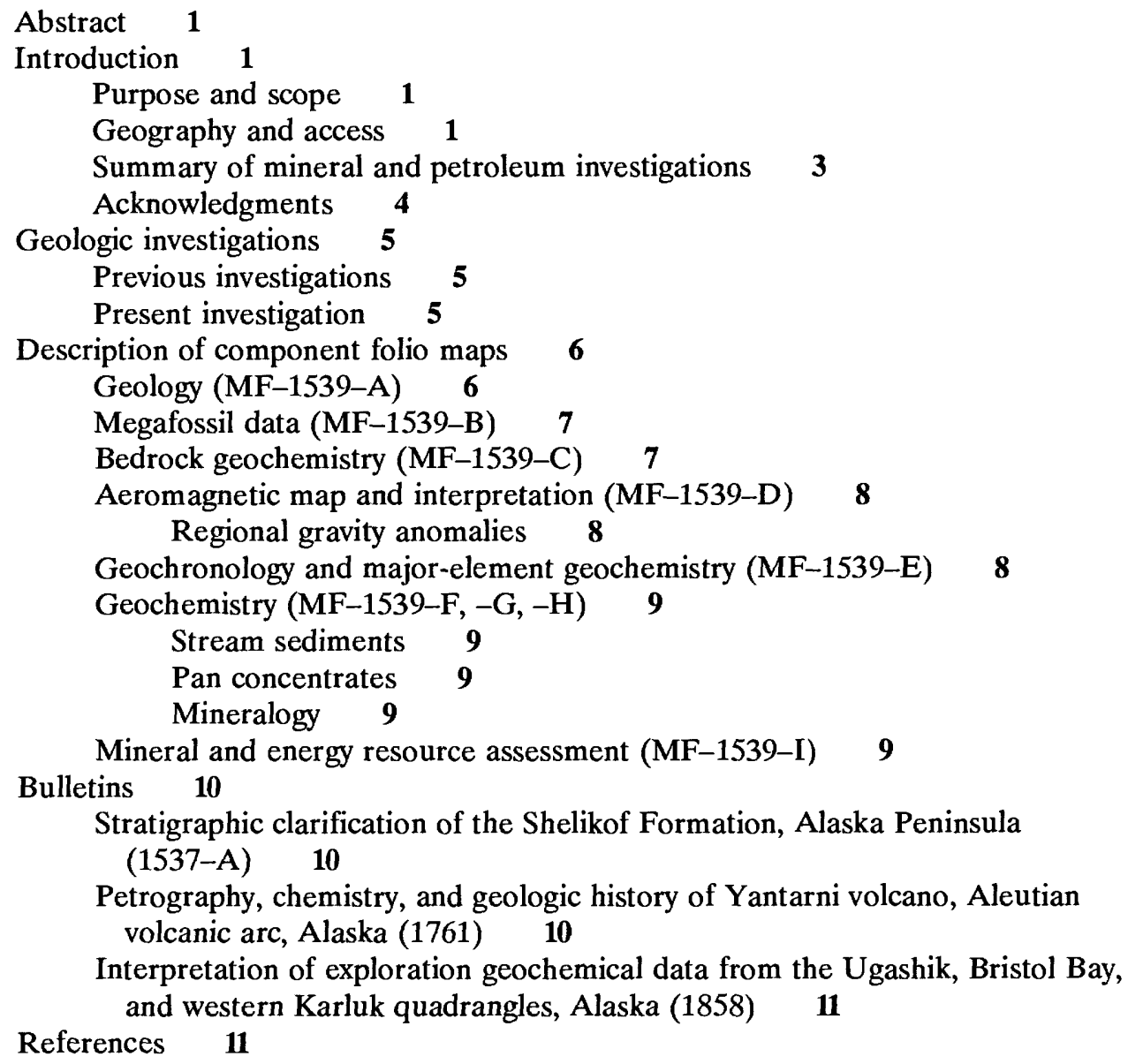

\section{FIGURES}

1. Location map showing study area on the Alaska Peninsula 2

2. Map of study area showing geographic features and physiographic provinces $\mathbf{3}$

3. Map of study area showing claims, prospects, exploratory wells, and areas of potential mineralization 4

\section{TABLES}

1. Component maps of the Ugashik, Bristol Bay, and western part of Karluk quadrangles, Alaska 2

2. Data on exploratory wells drilled for petroleum in the Ugashik and western part of Karluk quadrangles 5 


\title{
The Alaska Mineral Resource Assessment Program: Background Information to Accompany Folio of Geologic and Resource Maps of the Ugashik, Bristol Bay, and Western Part of Karluk Quadrangles, Alaska
}

\author{
By R.L. Detterman, J.E. Case, S.E. Church, J.G. Frisken, F.H. Wilson, and M.E. Yount
}

\begin{abstract}
The Ugashik, Bristol Bay, and western part of Karluk quadrangles $(1: 250,000)$ are a part of the Alaska Peninsula in southwestern Alaska. This circular, in conjunction with a companion folio of MF-series maps, two I-series geologic maps, and three bulletins, represents the results of integrated field and laboratory studies on the geology, geophysics, geochemistry, paleontology, geochronology, and mineral resources of the quadrangles. These studies were undertaken to provide a modern assessment of the mineral and energy resources of the quadrangles. Each map contains descriptive text, explanatory material, tables, diagrams, and pertinent references. This circular provides background information for the mineral resource assessment map (MF-1539-I) and integrates the component MF-and I-series maps. A comprehensive bibliography cites both specific and general references relevant to the geology and resources of the quadrangles.
\end{abstract}

\section{INTRODUCTION}

\section{Purpose and Scope}

This circular and the companion folio of related maps are a part of a series of U.S. Geological Survey reports designed to provide an inventory of Alaska's mineral resources. The reports furnish information for mineral and energy policy-making decisions by Federal and State governments, native corporations, and industry concerning the future use of Alaskan land and resources. This report and the folio of maps were prepared under the auspices of the Alaska Mineral Resource Assessment

Manuscript approved for publication, November 21, 1989.
Program (AMRAP) by a multidisciplinary team of earth scientists. Field and laboratory studies were conducted between 1979 and 1982.

The folio consists of nine maps that provide information on the geology, geochemistry, geophysi's, geochronology, paleontology, and mineral resourcer of the quadrangles (table 1). The primary intent of the folio and circular is to furnish mineral and energy resource data for land-use planning and long-term national resource policy decisions. Additional aims are to determine the time and type of mineral emplacement and to increase the geologic knowledge of an actively accreting continental margin and volcanic arc.

This circular contains references relevant to the Ugasik, Bristol Bay, and western part of Karluk quadrangles. Individual maps of the folio contain additional references applicable to their subject matter.

In addition to the folio maps, which are printed in black and white, two companion multicolor Miscellaneous Geologic Investigations Series Maps (Detterman and others, 1987a, b) have been published. Topical studies conducted during the investigations also resulted in three bulletins (Allaway and others, 1984; Richle and others, 1987; Church and others, 1989b), one masters thesis (Allaway, 1982), two circular articles (Detra and others, 1981; Allaway and Miller, 1984), and five openfile reports (Detterman and others, 1980, 19811 、1982; Wilson, 1982; Wilson and O'Leary, 1986).

\section{Geography and Access}

The Ugashik, Bristol Bay, and western part of the Karluk quadrangles encompass about $12,670 \mathrm{~km}^{2}(4,892$ $\mathrm{mi}^{2}$ ) on the Alaska Peninsula (figs. 1 and 2).

The study area is bounded by $57^{\circ}$ and $58^{\circ} \mathrm{N}$. lat. and by $155^{\circ}$ and $158^{\circ} 41^{\prime}$ W. long. (fig. 2). The Pacific 
Table 1. Component maps of the Ugashik, Bristol Bay, and western part of Karluk quadrangles, Alaska

$$
\begin{aligned}
& \text { U.S. Geological Survey } \\
& \begin{array}{c}
\text { Miscellaneous Field Studies } \\
\text { Map MF-1539 }
\end{array}
\end{aligned}
$$

-A (Detterman and others, 1983)

-B (Detterman and others, 1985)

$-\mathrm{C}$ (Wilson and O'Leary, 1986)

-D (Case and others, 1988)

-E (Wilson and Shew, 1988)

-F (Church and others, 1988)

$-G$ (Frisken and others, 1988a)

-H (Frisken and others, 1988b)

-I (Church and others, 1989a)
General geology

Fossil locality map, checklists, and stratigraphic sections

Bedrock geochemistry

Aeromagnetic map and interpretation

Geochronology and majorelement geochemistry

Geochemical distribution in stream sediments

Geochemical distribution in pan concentrates

Mineralogy of pan concentrates

Mineral and energy resource assessment map

Ocean side of the peninsula is dominated by the rugged mountains of the Aleutian Range, which rise abruptly from the sea and are cut by numerous fjords and bays. The highest peaks are in the southeastern part of the map area, where the Quaternary volcanoes Mount Kialagvik, Mount Chiginagak, and Mount Yantarni dominate the skyline. Mount Chiginagak $(2,120 \mathrm{~m})$ is the highest peak in the area. Small valley glaciers radiate from these volcanoes, and a small $\left(50 \mathrm{~km}^{2}\right)$ ice field lies east of Mount Kialagvik. From Wide Bay to Puale Bay the

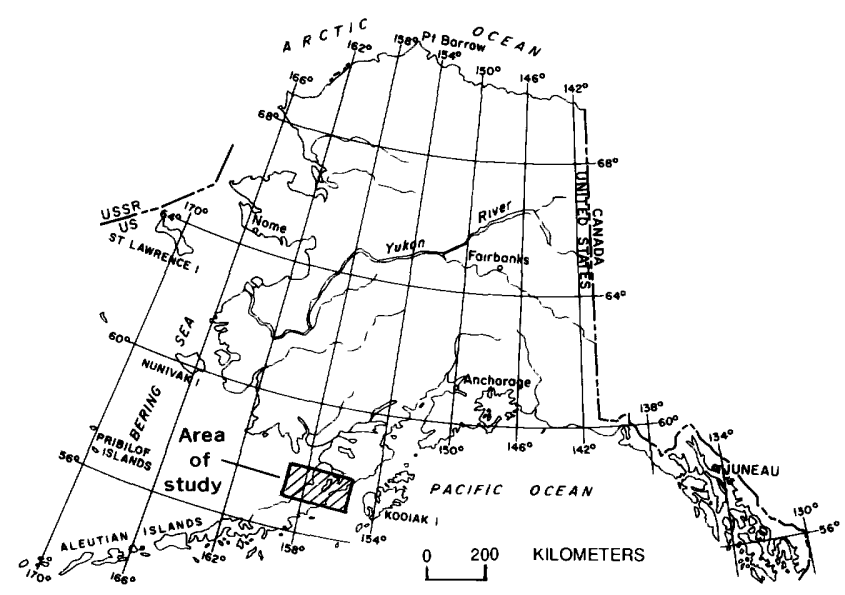

Figure 1. Index map showing location of study area.

mountains gradually decrease in height. North of Puale Bay they merge with the Kejulik Mountains of the Mount Katmai quadrangle. Mount Peulik $(1,475 \mathrm{~m})$; a Holocene stratovolcano, dominates the west side of this northern segment of mountains.

A broad, low, coastal plain west of the Aleutian Range slopes gradually northwestward from the mountains to Bristol Bay. Most of the low, rolling hills that dot the plain are remnants of glacial moraines that rarely exceed $100 \mathrm{~m}$ in elevation. Ash-flow tuff from Aniakchak Crater to the south covers the southwestern part of the map area, burying morainal ridges. The ash-flow-tuff plain, extending nearly $20 \mathrm{~km}$ into the area, was formed by a major eruption of Aniakchak Crater about 3,400 years ago (Miller and Smith, 1977, 1987).

Becharof Lake $\left(1,175 \mathrm{~km}^{2}\right)$, the second largest lake in Alaska, is mostly within the study area. Other large lakes include Upper Ugashik, Lower Ugashik, and Mother Goose. Hundreds of small glacial lakes and ponds dot the Bristol Bay Lowland. The large lakes are all confined behind terminal moraines of Pleistocene glaciers and are remnants of formerly much larger lakes (Detterman and others, 1987b). Becharof Lake and the Ugashik Lakes are less than $5 \mathrm{~m}$ above modern sea level, and most of the numerous other lakes and ponds are within $30 \mathrm{~m}$ of sea level.

Three major river systems, the Ugashik, King Salmon, and Dog Salmon, drain the western part of the map area. All three empty into Ugashik Bay after following meandering courses across a nearly flat, former lakebed deposit (Detterman and others, 1987b). The three rivers combined drain about two-third s of the map area and, even though they are low-gradient streams, carry a large volume of water. Another major westflowing stream, the Kejulik River, flows in ${ }^{+} \mathrm{O}$ Becharof Lake and drains the northeastern part of the map area. The Egegik River, north of the map area. runs from Becharof Lake to Bristol Bay. Streams drairing into the Pacific Ocean are all short with steep gradie nts.

Only two permanent villages exist in the map area: Pilot Point with a population of 66, and Uga hik with 13 residents (year-round population from 1980 census). Populations of both towns increase markedly during the summer months owing to commercial fishing. Numerous hunting and fishing camps near the major lakes and rivers are occupied seasonally. At the present time (1988) there are no settlements on the Pacific Ocean side of the peninsula within the map area. The former village of Kanatak, at the head of Portage Bay, has been abandoned for many years.

Access to the area is only by aircraft or boat. Moderate-sized twin-engine aircraft can land at Pilot Point and near Painter Creek, but other landing areas are usable only by smaller aircraft. Most of the hunting and fishing camps maintain small, private airstrip. There are no public roads within the map area. A few miles of 
gravel roads are present around Pilot Point and near the camps. Most were constructed during exploration for petroleum.

\section{Summary of Mineral and Petroleum Investigations}

The Ugashik and western part of Karluk quadrangles have been the site of intermittent exploration for minerals and petroleum since the early 1900's, but no economic deposits have been located. The earliest authenticated exploration for minerals occurred in 1915, when placer gold claims were established at Cape Kubugakli (fig. 3). These claims were reported to have produced about 160 ounces of gold (Smith, 1925). Nothing is known concerning more recent activity on these claims, but mining equipment was found when the site was visited in 1977. Copper ore containing minor amounts of gold and silver was reportedly found near the head of Puale Bay in 1920 (Berg and Cobb, 1967). Our investigations failed to locate this deposit.

Recent mineral exploration was confined to the southern part of the area. Bear Creek Mining Company did some diamond drilling in 1977 and 1978 on a molybdenum porphyry prospect (Mike prospect) in the mountains near the head of Painter Creek. During this same period they discovered a gold, silver, and copper prospect (Rex prospect) in the mountains between Volcano Creek and Dog Salmon River.

Exploration for petroleum in the Ugashik and Karluk quadrangles has been much more intense than that for minerals, probably because the presense of oil seeps and the exposure of a thick sedimentary rock section. The first wells in the area were drilled between 1902 and 1904 near oil seeps on Oil Creek (Martin, 1904, 1905; Capps, 1923; Smith, 1926). The locations of these wells and nearly all others are shown on the ger ralized geologic map prepared by Detterman and others (1983). Since the publication of that map, AMOCO Production Company completed the drilling of the Becharof \#1 well in 1985. Data for exploratory wells drilled in the map area are listed in table 2.

Despite the presence of oil and gas seeps in the area, exploration to date has yielded only a modest show of oil. Diagenetic alteration of the abundant volcanic debris in the sediments has greatly reduced the porosity and permeability of these rocks. Thus, rocks with good reservoir characteristics have not been encountered in drilling. Most of the oil and gas seeps are located near faults that probably provide a pathway to the surface.

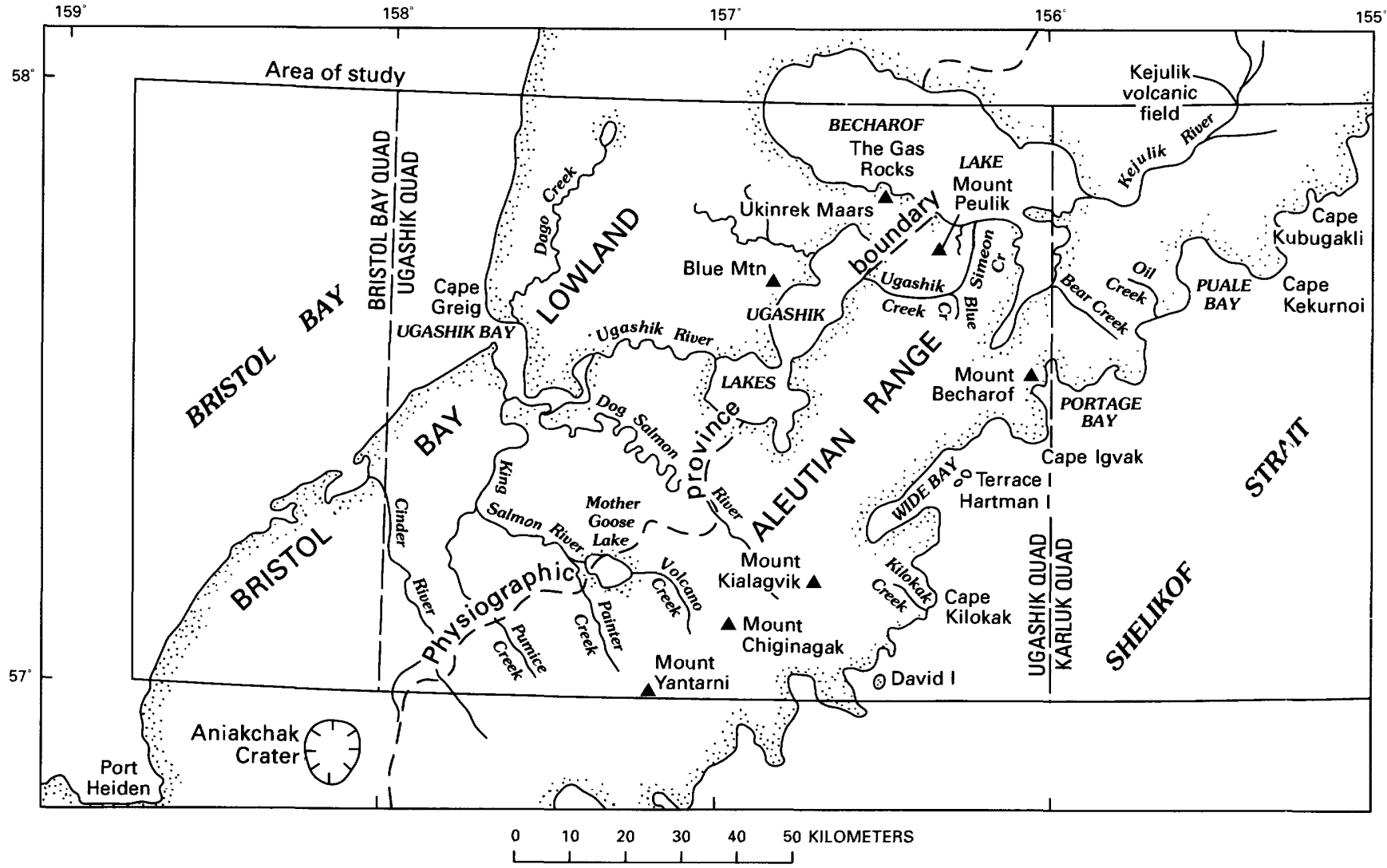

Figure 2. Area of study showing geographic features and physiographic provinces. 
Two areas of oil seeps are located within the quadrangles. The main area is along the crest of the Bear Creek anticline where it crosses Bear Creek and Oil Creek. These seeps were reported as early as 1869 (Capps, 1923). The oil is seeping from rocks of the Shelikof Formation and has formed areas of tarlike residue on the surface. A second area of seeps is southeast of Mount Peulik, near the crest of the Ugashik anticline in an area known as Pearl Creek dome. Patches of bright-green, fresh oil can be seen on Ugashik Creek and Blue Creek. Areas of residue have formed where the oil collected and was exposed to the air for long periods. These mounds of tarlike residue were used to fuel boilers during early drilling operations. One additional area of seepage was found along Simeon Creek during the current investigation. All seeps on the Ugashik anticline are from the Naknek Formation.

In addition to seepages of oil, there are also seepages of gas in the region, some of which are associated with oil seeps and are of obvious biogenic origin. Other large seeps, such as around The Gas Rocks, are of inorganic origin. Gas collected and analyzed from The Gas Rocks seeps is about 98 percent carbon dioxide (Barnes and McCoy, 1979). The location and analyses of all oil and gas samples from the area were reported by Blasko (1976).

\section{Acknowledgments}

Geologic investigations in the Ugashik, Bristol Bay, and western part of Karluk quadrangles were facilitated greatly by the efforts of many geologists, both from the U.S. Geological Survey and private industry, whose many contributions are greatly appreciated. The work of most visiting scientists, short-term workers, ant laboratory specialists is acknowledged on individual maps in the folio. The contributions of some specialists, although not mentioned specifically on the maps, were of great benefit to the project. Among those to whom special tribute is due are J.A. Wolfe, R.W. Imlay, J.W. Miller, and C.D. Blome of the U.S. Geological Survey, and John Calloman of the University of London, paleontologists whose identifications of many collections of invertebrete and plant fossils helped in determining the stratigraphic succession of the sedimentary units. J.R. Riehle, M.L. Silberman, and Nora Shew made significant contributions to our understanding of the complex eruption history of the volcanoes as well as of the numerous intrusive events.

Work in such a remote project area would be impossible without the willing assistance of local residents. Among those who were of great service to the project were the people at Painter Creek I odge, especially J.W. Smith, who provided the project with food and

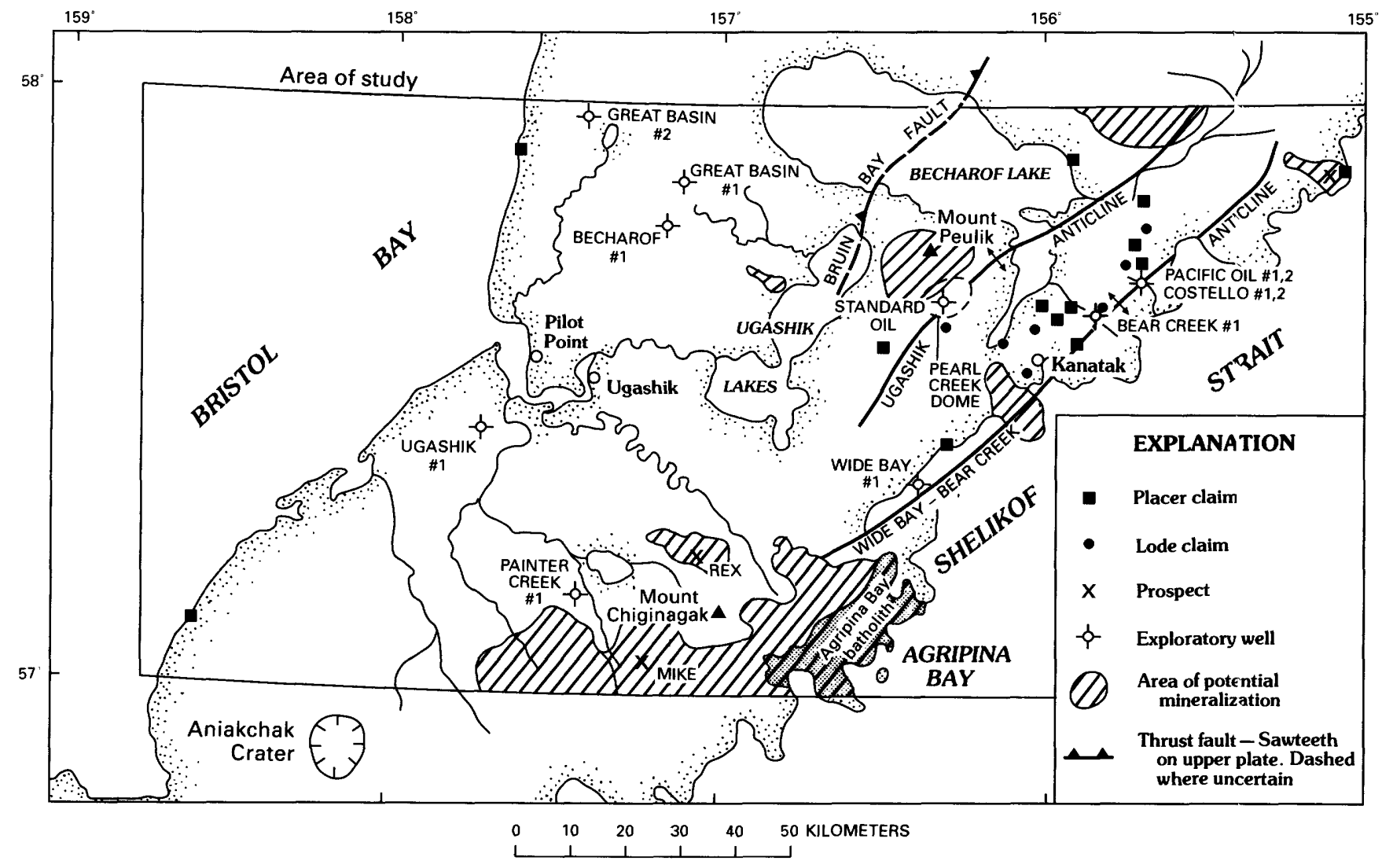

Figure 3. Area of study showing claims, prospects, exploratory wells, and areas of potential mineralization. 
Table 2. Data on exploratory wells drilled for petroleum in the Ugashik and western part of Karluk quadrangles [U., Upper; Do. (do.), ditto]

\begin{tabular}{|c|c|c|c|c|c|}
\hline Well & Company & $\begin{array}{c}\text { Year } \\
\text { completed }\end{array}$ & Location & $\begin{array}{l}\text { Depth } \\
\text { (in feet) }\end{array}$ & $\begin{array}{l}\text { Formation } \\
\text { at tota' depth }\end{array}$ \\
\hline Pacific Oil \#1 ---------- & Pacific Oil \& Commercial -.-- & 1903 & NW'/4 sec. 3, T. 29 S., R. 40 W. & 1,421 & Sheli of \\
\hline Pacific Oil \#2 ---------- & - & 1904 & SEY sec. 3, T. 29 S., R. 40 W. & 1,542 & D. \\
\hline Costello\#1 -.---a--- & J.H. Costello -........... & 1903 & NW'/4 sec. 10, T. 29 S., R. 40 W. & 728 & D. \\
\hline Costello \#2 …........ & 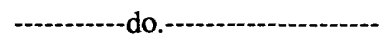 & 1904 & SE $4 / 4$ sec. 10 , T. 29 S., R. 40 W. & Unknown & Unkrown \\
\hline 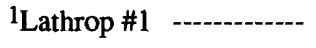 & Standard Oil Calif. -...-....... & 1923 & SE 4 sec. 17, T. 29 S., R. 43 W. & 500 & Nakrek \\
\hline${ }^{1}$ McNally \#1 ................ & 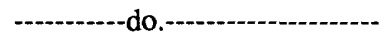 & 1925 & NW/4 sec. 29 , T. 29 S., R. 43 W. & 510 & D?. \\
\hline Lee \#1 - - - & 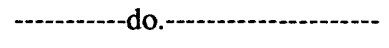 & 1926 & SW/4 sec. 20, T. 29 S., R. 43 W. & 5,034 & Unkrown \\
\hline 2Finnegan \#1 -.--.----- & Tidewater Associated -------- & 1923 & NEK/ sec. 30, T. 29 S., R. 43 W. & 560 & Nakrek \\
\hline 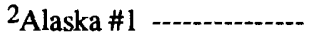 & 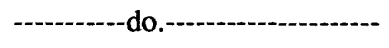 & 1926 & SW/4 sec. 20, T. 29 S., R. 43 W. & 3,033 & Shelikof \\
\hline 2Grammer \#1 ---------- & Standard Oil Calif. ---_-_---- & 1940 & SE 4 sec. 10, T. 30 S., R. $41 \mathrm{~W}$. & 7,596 & Unkrown \\
\hline Bear Creek Unit \#1 ----- & Humble Oil \& Refining -..--.-- & 1959 & NE $/ 4$ sec. 36, T. 29 S., R. 41 W. & 14,375 & $\begin{array}{l}\text { Unnamed } \\
\text { U. Triassic }\end{array}$ \\
\hline Great Basins \#1 -------- & General Petroleum Co. & 1959 & SW/̌ sec. 2, T. 27 S., R. 48 W. & 11,080 & $\begin{array}{l}\text { U. Jivassic } \\
\text { bath olith }\end{array}$ \\
\hline Great Basins \#2 ------- & 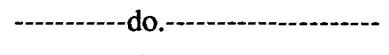 & 1959 & SE 4 sec. 35, T. 25 S., R. 50 W. & 8,865 & D). \\
\hline Wide Bay \#1 & Richfield Oil and others & 1963 & NW' sec. 5, T. 33 S., R. 44 W. & 12,568 & $\begin{array}{l}\text { Unnamed } \\
\text { U. Triassic }\end{array}$ \\
\hline 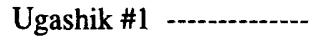 & Great Basins Oil Co. -.......... & 1966 & SE $/ 4$ sec. 8, T. 32 S., R. 52 W. & 9,476 & Mesl $\mathrm{k}$ \\
\hline Painter Creek \#1 -------- & Cities Service Oil Co. ---.---- & 1967 & NW/4 sec. 14, T. 35 S., R. 51 W. & 7,912 & Shelikof \\
\hline${ }^{2}$ Becharof/State \#1 ----- & AMOCO Production Co. ----- & 1985 & NW' sec. 10, T. 28 S., R. 48 W. & 9,023 & Unknown \\
\hline
\end{tabular}

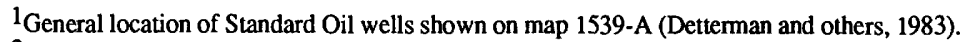

${ }^{2}$ Locations not shown on map.

lodging during 1982 and 1983 and aided in many phases of the logistic support that made completion of the project possible. Thanks are due also to the personnel at Ugashik Lake Lodge, who provided similar services in 1979.

Special commendations are due Captain A.C. "Frosty" Frothingham and the crew of the U.S. Geological Survey Research Vessel Don J. Miller II, who cheerfully provided us with a base of operations during the 1980 and 1981 field seasons. Our helicopter pilots Lucky Wilson, Richard Rossiter, Edward Svec, and Tom Robbins often flew in adverse weather conditions to take us to our work sites, and we greatly appreciate their skill and professionalism.

\section{GEOLOGIC INVESTIGATIONS}

\section{Previous Investigations}

The first important generalized contributions to the geology of this area were by Dall and Harris (1892) and Dall (1896). More detailed geologic investigations by Capps (1923), Smith and Baker (1924), and Smith (1925, 1926) were made following the early petroleum explora- tion at Bear Creek anticline and Pearl Creel dome. Martin (1926) made the first major attempt to correlate the Mesozoic stratigraphic units and show how they relate to the rest of Alaska.

The first modern synthesis of the stratigraphy and structure of the Alaska Peninsula, including part of the Ugashik quadrangle, by Burk (1965) provided the foundation for the present geologic investigation.

\section{Present Investigation}

Field work and laboratory analyses for the present study were started in 1979 and completed in 1082. The geologic mapping was at a scale of 1:63,360 (1 inch=1 mile). Both geologic mapping and geochemical sampling were helicopter supported. Mapping of the Mounts Peulik and Chiginagak volcanoes, begun by T.P. Miller during 1974 and 1975, was continued during the present investigation.

This study was a part of the Alaska Minoral Resource Assessment Program (AMRAP) for the Alaska Peninsula and was supervised by R.L. Detterman. Most of the field-mapping personnel were also responsible for a particular topical phase of the work. F.H. Wilson 
obtained potassium-argon ages for the intrusive and extrusive rocks, J.E. Case was responsible for aeromagnetic interpretations, M.E. Yount and J.R. Riehle mapped the Quaternary volcanic rocks, and J.W. Miller carried out paleontological investigations.

During the course of this study, 1,360 sites were occupied for geologic data, and 585 stream-sediment samples and 569 heavy-mineral pan-concentrate samples were collected to provide a data base for the mineral resource assessment. In addition, 337 bedrock samples were collected at geologic stations for semiquantitative spectrographic analysis; these include both mineralized samples and unmineralized specimens for a background data base. Prior to the present study, only four published potassium-argon (K-Ar) ages were available for the rocks of the Ugashik and western part of Karluk quadrangles (Reed and Lanphere, 1969, 1972; Brockway and others, 1975; Wilson and others, 1981). A total of 57 new K-Ar ages have been added (Wilson and Shew, 1982, 1988). These ages permit a determination of the intrusive and extrusive history of the quadrangles, as well as of the time of mineral emplacement. During the present investigation, 376 collections of fossil megafauna and megaflora were made from sedimentary rocks of the quadrangles; these collections provide a strong framework for relative dating of the sedimentary sequence and form a means of correlating the potassium-argon (K-Ar) ages from associated igneous rocks. Data from these fossil collections were listed by Detterman and others (1985).

Aeromagnetic surveys were flown for the eastern part of the map area by Fugro Geometrics Inc. in 1980 and by Diversified Technical Services, Inc. in 1982 (U.S. Geological Survey, 1984), under contract to the U.S. Geological Survey. The aeromagnetic interpretation map was compiled by Case and others (1988). Scintillometer data were collected at many of the bedrock sample localities (Detterman and others, 1981b, 1982).

\section{DESCRIPTION OF COMPONENT FOLIO MAPS}

\section{Geology (MF-1539-A)}

The Ugashik, Bristol Bay, and western part of Karluk quadrangles form a transverse segment across the active Aleutian volcanic arc. This map area also includes a segment of a middle Tertiary volcanic arc and plutonic rocks of a still older Mesozoic magmatic arc. The entire area is part of a collage of fragments sutured to Alaska during Jurassic and later time (Jones and others, 1978; Coe and others, 1985). Paleomagnetic data suggest that some Mesozoic rocks of the Alaska Peninsula may have originated a considerable distance south of their present latitude (Packer and Stone, 1974; Stone and Packer, 1979). Continuing subduction of the Pacific plate be- neath the North American plate along the Aleutian Trench at a rate of about $5 \mathrm{~cm} / \mathrm{yr}$ (Kerr, 1987) accounts for numerous Pleistocene and Holocene volcanoes and for the earthquakes common to the area.

The oldest rocks of the Alaska Feninsula are exposed in this map area at Puale Bay. Fermian limestone crops out on one small island at the muth of Puale Bay. Along the north shore of the bay are exposures of a thick section of Upper Triassic limestone and volcanic rocks of an old magmatic arc. Both the Permian and Triassic limestones were probably deposited far to the south in seas warmer than the modern North Pacific Ocean.

We have determined, as a result of our investigations, that a nearly continuous sequence of Jurassic sedimentary rock is exposed within the Ugashik and Karluk quadrangles. Minor hiatuses are present in the stratigraphic record, but no major unconformities are represented. This depositional record coincides with the period during which the land fragment that is now the Alaska Peninsula drifted from more southerly latitudes northward to near its present latitude. Ammonites from the Lower Jurassic strata at Puale Bay show a close correlation to forms now found in Lower Jurassic strata at the latitude of Mexico (Imlay, 1980). A mmonites of Middle Jurassic age correlate more close'y with those from areas north of Mexico. The Late Jurassic megafauna of the Ugashik and Karluk area consist almost entirely of the bivalve Buchia, found worldwide only in the boreal regions. Many changes in depositional environments accompanied the northward shift in latitude. The Permian and Triassic limestone was deposited on an open, shallow-water shelf in tropical seas. The Lower Jurassic sediments were also deposited in shallow water. But by the Middle Jurassic, deep-water turbidite: were being deposited in part of the area. Upper Jurassic strata are shallow-water shelf to nonmarine deposits.

Intrusive and extrusive igneous rocks of Jurassic age are also exposed in the map area, northwest of the Bruin Bay fault. A small exposure of Mitdle Jurassic plutonic rocks formed an island in Bechar ff Lake near The Gas Rocks (Reed and Lanphere, 1969, 1972). Similar Jurassic plutonic rocks also have been en ountered in boreholes on the Bristol Bay coastal plain (Frockway and others, 1975).

An extended period of erosion and nondeposition followed the Jurassic, and thus the next ovarlying strata preserved are of Late Cretaceous age. Cont nued tectonic activity has caused the removal of most Upper Cretaceous shelf and slope deposits, leaving no more than $\mathbf{5 0}$ to $75 \mathrm{~m}$ of strata. Lower Tertiary strata urconformably overlie the older beds. The oldest Tertiary strata in the map area are early Eocene continental deposits commonly containing abundant petrified logs and coal seams. Orogenic activity during the Tertiary probably resulted from subduction along the proto-Aleutian "rench. 
Meshik arc volcanism (as defined by Wilson, 1985) started in the late Eocene and deposited a thick sequence of subaerial basaltic-to-andesitic fragmental volcanic rocks and massive lava flows from vents along the west side of the modern mountains. Activity along the arc continued for 12 to $15 \mathrm{~m}$.y. and tapered off during the Oligocene. A thick section of these volcanic rocks is exposed in the southwestern part of the map area. Owing to the strong magnetic character of these rocks (Case and others, 1981), it is possible, based on aeromagnetic data, to trace them partly across the map area beneath a mantle of glacial drift.

Volcanic activity along the Meshik arc ceased in this area about 24 to $23 \mathrm{~m}$.y. ago (Wilson, 1985). Thereafter, these deposits, along with the older rocks, were uplifted and reworked by erosion into the overlying sedimentary sequence. A thick late Tertiary sedimentary section is preserved mainly in the subsurface of the Bristol Bay coastal plain, where it is covered by glacial drift but has been penetrated by the Great Basins \#1 and \#2 wells and by the Ugashik \#1 well (Brockway and others, 1975). A thin sequence of the Upper Miocene Bear Lake Formation is exposed along faults near the Ugashik Lakes.

Volcanic activity along the Aleutian volcanic arc probably originated about 10 to $5 \mathrm{~m}$.y. ago with the renewal of igneous activity along the Alaska Peninsula. In the Ugashik and Karluk quadrangles area this was restricted mainly to the emplacement of quartz diorite plutons, such as the Agripina Bay batholith, along the Pacific coast side of the mountains. Dacite intrusions associated with mineral deposits also occurred during this interval. Minor extrusive activity accompanied the emplacement of these plutons. Large-scale volcanic activity along this part of the arc commenced about 1.9 to 1.5 m.y. ago at Blue Mountain, The Gas Rocks, Mount Yantarni volcano, and possibly other sites; it has continued until the present with the eruption at Ukinrek Maars in 1977.

Tectonic activity associated with subduction along the proto-Aleutian Trench has resulted in numerous high-angle reverse faults and some thrust faulting. The Bruin Bay fault, a major fault in southern Alaska, enters the northern edge of the study area, but disappears beneath surficial deposits south of Becharof Lake. Transverse faulting and fracturing is very common. The northeast trend of Aleutian Range volcanoes is offset about 20 $\mathrm{km}$ in the Ugashik and Karluk quadrangles. This may be due to plumbing or structure of the downgoing slab rather than offset of crustal segments.

\section{Megafossil Data (MF-1539-B)}

Considerable amounts of new data on the fossil megafauna and megaflora were obtained during the present investigation. A total of 353 collections $\mathrm{c} f$ marine megafauna and 23 collections of megaflora from nonmarine Tertiary strata were made during the invertigation, adding considerably to the data base for the area. Collections were made from rocks ranging in age from Late Permian to Eocene. These collections permit time-stratigraphic correlations to be made for the various rock units.

The Kialagvik, Shelikof, and Naknek Formations, of Middle and Late Jurassic age, are abundantly fossiliferous and account for 67 percent of all fossil collections. Ammonites constitute the main elements of the megafauna in the Talkeetna, Kialagvik, and Shelikof Formations, including 36 species belonging to 23 genera. Marine bivalves of the genus Buchia are the age-diagnostic fossils in the Upper Jurassic Naknek Formation. Four species from closely controlled sections permit a precise zonation for this genera that can be used throughout the Alaska Peninsula (Miller and Detterman, 1985).

Nonmarine megaflora obtained from the Tolstoi Formation were identified by J.A. Wolfe (written commun., 1985) as early Eocene. This indicates that the Tolstoi Formation in the Ugashik and Karluk quadrangles is equivalent to only the upper part of the same formation exposed farther south on the peninsula (Detterman and others, 1981c).

\section{Bedrock Geochemistry (MF-1539-C)}

As an aid to the mineral resource assessment of the mapped area, 337 rock samples were collected and analyzed using 30-element semiquantitative emission spectrometry, additional atomic absorption spe-trophotometry, and other analytical methods. Sampling was conducted throughout the area in an effort to determine background concentrations; however, sampling was concentrated in areas of known or suspected mineralization and may be somewhat biased.

Anomalous samples were collected in a number of areas on the periphery of the Agripina Bay tatholith, near the plutons at Mount Becharof and Cape Igvak, and at Cape Kubugakli. Additionally, numerous anomalous samples were collected at the Mike and Rex prospects. No sampling or mapping was able to locate the reported copper mineralization at the head of Puale Bay (Perg and Cobb, 1967).

The data were statistically analyzed to select background and anomalous levels. Anomalous metal assemblages are consistent with mineralization models predicting copper and molybdenum porphyry-type mineralization with associated gold and silver. However, it was not possible to evaluate the background levels of metals in individual stratigraphic units because of insufficient sampling for statistical validity. 
Aeromagnetic Map and Interpretation (MF-1539-D)

Aeromagnetic surveys of most of the Ugashik and western part of Karluk quadrangles were flown in 1980 and 1982. The data obtained from the two surveys were combined, and some data from National Uranium Resource Evaluation (NURE) surveys were incorporated to produce a smoothed final map for publication.

Over the Bristol Bay Lowland, broad ovoid highs of 200 to 500 gammas are produced by deep-seated granitoid plutonic bodies, which are thought to be part of the Alaska-Aleutian Range batholith of Jurassic to Tertiary age (Reed and Lanphere, 1969, 1972). Gentle gradients on the flanks of the anomalies indicate that the sources of the anomalies are buried at depths of 3 to $4 \mathrm{~km}$ or more. One of the anomalies, near Cape Greig, coincides with a positive gravity anomaly of about $15 \mathrm{mGal}$ (Barnes, 1977b), and the source may be a dense and magnetic phase of the batholith, perhaps dioritic or gabbroic.

Conglomerate and sandstone derived by erosion of the batholith form the Upper Jurassic Naknek Formation. The conglomerate and some of the sandstone contain a high proportion of magnetite. Elongate northeastern-trending magnetic highs of 200 to 500 gammas are produced by magnetite-rich sandstone in the Naknek near the Ugashik Lakes. Another northeasttrending high of 400 gammas over covered areas to the northwest is interpreted to be caused by the Naknek on the northwest limb of an anticline.

Volcanic rocks of the Meshik Formation (Eocene and Oligocene) produce elongate positive anomalies as much as 1,000 gammas in amplitude along the northwestern front of the mountain belt. Other Tertiary volcanic rocks elsewhere in the Ugashik and Karluk quadrangles cause irregular highs and lows of about 50 to 200 gammas.

Many of the Tertiary granitoid plutons cause ovoid magnetic highs of 200 to 1,000 gammas or more. Similar anomalies are in water-covered areas east of Cape Kilokak, east of Hartman and Terrace Islands, and elsewhere, and these are interpreted to result from Tertiary plutons. Most of the known ore deposits, prospects, and geochemical anomalies of the area are associated with the Tertiary plutons or their hornfelsed and altered wall rocks. Thus, the ovoid magnetic anomalies constitute guides to exploration, as in the Chignik and Sutwik Island quadrangles to the south (Case and others, 1981). A few magnetic lows or magnetically flat areas associated with Tertiary intrusive and extrusive rocks may indicate hornfelsing or hydrothermal alteration and may serve as a secondary guide to exploration.

Quaternary volcanic centers at Mount Chiginagak, Mount Kialagvik, Mount Peulik, and Blue Mountain cause short-wavelength positive anomalies of 200 to 1,000 gammas or more.

\section{Regional Gravity Anomalies}

Gravity data are sparse in the mountair ous parts of the Ugashik and western part of Karluk auadrangles. Barnes' (1977b) map shows a negative anomaly of about $10 \mathrm{mGal}$ in the southwestern part of the Bristol Bay Lowland, continuing northeast to near the Kejulik River. This low is caused by the thick accumulation ( 3 to $4 \mathrm{~km}$ or more) of Tertiary sedimentary rocks of low density. The relative gravity high of 10 to $15 \mathrm{~m}$ Gal in the northwest, near Cape Greig, may indicate a mafic pluton at depth, or shallower depth to basement.

A positive anomaly of 30 to $50 \mathrm{mGal}$ t"ends northeast along the mountainous part of the perinsula. This positive anomaly is an extension of the major gravity high over the Aleutian Islands and may be caused by oceanic crust at depth (Case and others, 1981).

\section{Geochronology and Major-element Geochemistry (MF-1539-E)}

A total of 57 new K-Ar ages were determined in conjunction with the AMRAP mapping studies and help to provide a well-constrained time scale for Tertiary and Quaternary events and stratigraphic relations. In addition, 54 new and 12 previously reported major-element chemical analyses were compiled and analyzed.

The ages are approximately evenly divited in number between the late Tertiary Aleutian magmatic arc and samples representative of the Meshik (early Tertiary) and Jurassic magmatic arcs. A number of samples were collected to date hydrothermal alteration ass ciated with mineralization. Significant among these were samples collected on the periphery of the late Pliocene Agripina Bay batholith at Kilokak Creek and soutl of Mount Kialagvik. In both cases, hydrothermally altered phases yielded Oligocene ages, equivalent to that of the Meshik arc, which suggests that the area of the batholith was the site of magmatic activity and alteration during the timespan of both Tertiary magmatic arcs. Age determinations of Meshik-age plutonic rocks at the Rex prospect indicate hydrothermal and magmatic activity occurred in multiple phases, spanning approximately 4.5 m.y.

Major-element chemical analyses shcw rocks of both arcs to be of calc-alkaline affinity, though a few samples, including some from the Kejulik vol-anic center of Quaternary age, lie in the tholeiitic field on a $\mathrm{SiO}_{2}$ versus $\mathrm{FeO}^{*} / \mathrm{MgO}$ plot. The samples collerted can be divided into a number of suites on the basis of age and geologic setting. These suites are chemically distinct on many elemental plots and indicate varying ranges and trends of major elements with respect to silica. Both the Agripina Bay batholith suite and the suite cf plutons at Mount Becharof and Cape Igvak intrude similar rocks, are compositionally similar, and are of essentially the 
same age, yet they differ chemically. The Agripina Bay suite has the highest $\mathrm{K}_{2} \mathrm{O}$ level (1.8 percent at 57.5 percent $\mathrm{SiO}_{2}$ ), whereas the Mount Becharof-Cape Igvak suite has the lowest $\mathrm{K}_{2} \mathrm{O}$ level $(0.9$ percent at 57.5 percent $\mathrm{SiO}_{2}$ ) of all suites.

\section{Geochemistry (MF-1539-F, -G, -H)}

A reconnaissance exploration geochemical study was undertaken during the 1979 and 1980 field seasons. Two diffferent media were sampled: (1) stream sediments and (2) heavy-mineral concentrates panned from the stream sediments. A total of 585 minus-80-mesh stream-sediment samples and 569 panned-concentrate samples were collected from active channels of streams draining $5-16 \mathrm{~km}^{2}$. The minus- 80 -mesh stream-sediment medium reflects changes in bedrock geology and geochemistry and indicates areas of extensive exposed mineralization. A 14-in. gold pan full of minus-2-mm stream sediment was collected from the high-energy part of the stream to obtain each panned-concentrate sample. Each sample was further processed in the laboratory through heavy liquids to remove the light-mineral fraction (sp gr $<2.8$ ) and through a magnetic separation process to remove magnetite as well as many of the more magnetic mafic minerals. The nonmagnetic, heavy-mineral fraction analyzed for this study contained high-specific-gravity, rock-forming minerals such as apatite, zircon, rutile, and sphene; the sulfide, sulfosalt, and some oxide minerals; and several of the accessory minerals associated with mineralization and alteration such as scheelite, fluorite, barite, epidote, and tourmaline. The nonmagnetic fraction of the heavy-mineral concentrates should reflect the presence of ore-related minerals and therefore may be useful in delineating areas of poorly exposed mineralization. All analyses were by the semiquantitative emission spectrographic method described by Grimes and Marranzino (1968) and by Motooka and Grimes (1976); supplementary determinations of $\mathrm{Cu}, \mathrm{Pb}$, and $\mathrm{Zn}$ concentrations were made by atomic absorption (Ward and others, 1969). A detailed description of the geochemical sampling, sample preparation, and analytical methods utilized is presented, along with the tabulated geochemical data and sample-locality maps, by Detra and others (1981).

\section{Stream Sediments}

The distribution of the elements $\mathrm{Cu}, \mathrm{Mo}, \mathrm{Ag}, \mathrm{Pb}$, $\mathrm{Zn}, \mathrm{B}, \mathrm{Ni}$, and Co are shown on MF-1539-F (Church and others, 1988). Anomaly thresholds were chosen from an analysis of the bedrock geochemistry and vary depending upon the bedrock. Three classes of anomalous values for each element are shown using vectors surrounding a central point that indicates the sample locality. Elemental groupings can be determined from the pattern of the "star" at each sample locality. Histograms of these eight elements are also shown. A statistical summary is also given for the entire set of data reported by Detra and others (1981).

\section{Pan Concentrates}

For the nonmagnetic heavy-mineral conce itrates, the distribution of the elements $\mathrm{Cu}, \mathrm{Mo}, \mathrm{Ag}, \mathrm{Pb}, \mathrm{Zn}, \mathrm{B}$, $\mathrm{Ni}$, and $\mathrm{Co}$ is shown on map $\mathrm{A}$ and of the elements As, $\mathrm{W}, \mathrm{Au}, \mathrm{Bi}, \mathrm{Cd}, \mathrm{Ba}, \mathrm{Nb}$, and $\mathrm{Sn}$ on map B of MF-1539-G (Frisken and others, 1988a). Thresholds were chosen from an analysis of the distributions of each element from the data and are shown on histograms. Three classes of anomalous values for each element ar? shown using the "star" diagram; elements are grouped so that geochemically coherent sets of elements are presented on maps A and B. The set of elements displayed on map A of MF-1539-G is identical to that on the streamsediment geochemical map (MF-1539-F).

\section{Mineralogy}

Spatial distribution and abundance of pyrite, chalcopyrite, molybdenite, galena, sphalerite, cinnat ar, barite, gold, tourmaline, zircon, and mafic minerals are presented in MF-1539-H (Frisken and others, 1988b). Abundances were determined by microscopic examination of the nonmagnetic heavy-mineral concentrates. Relative abundance is indicated by the lengtl of the vectors of the star diagrams, and the mineral vertors are chosen so that they correspond to the associated vectors on nonmagnetic heavy-mineral concentrate maps (MF1539-G).

\section{Mineral and Energy Resource Assesrsment (MF-1539-1)}

The mineral potential of the study area is summarized on MF-1539-I utilizing the mineral-deposit models outlined by Cox and Singer (1986). The geothermal, oil and gas, and coal resources of the area are also assessed on MF-1539-I.

Previous mineral-exploration activity in the Ugashik-Karluk area was limited largely to gold prcspecting near the turn of the century and to regional reconnaissance by major mining companies in the 1S70's for porphyry deposits and related mineralization. $\mathrm{N}$ ine lode claims and 13 placer claims have been staked in the area. Detailed field mapping and geochemical sampling by Kennecott Corporation on the Mike and Rex frospects were made available to the U.S. Geological Survey.

Eight tracts of land, each having somewhat different geologic characteristics, have been outlined as poten- 
tial mineral resource areas. On the basis of our work in the area, the geochemical anomalies directly associated with young intrusives, of observed patterns of alteration, and of permissive geologic criteria, we estimate that there is a 10-percent chance for two or more undiscovered porphyry copper deposits in the Ugashik-Karluk study area. From the limited drilling information on the Mike prospect, we estimate that there is a 90 percent chance of one or more porphyry molybdenum deposits and a 10 percent chance of two or more such deposits in the study area. Based on the $\mathrm{Cu} / \mathrm{Au}$ ratio in surface rock samples from the Rex prospect, we estimate a 90 percent chance of one or more porphyry copper-gold deposits in the study area.

The estimate of the abundance of smaller deposits is less concise because of the reconnaissance nature of our studies. The geologic environment in many of these tracts is permissive for polymetallic vein and epithermal gold-vein deposits. The mineralization exposed on David Island indicates a volcanic-hosted copper-arsenic-antimony deposit. The large magnetic anomalies surrounding the pluton at Cape Igvak and the geochemical signature associated with them suggest that an iron or tungsten skarn may be present.

Small gold placers may exist in the study area, particularly around the area of the Rex prospect, where gold was seen in several panned samples.

There are adequate resources of sand and gravel, cinder, and pumice to satisfy local demand. Limestone on Cape Kekurnoi is suitable as building stone and is adjacent to a protected deep-water port. Given sufficient local demand, this limestone unit is considered marginally economic.

A geothermal energy resource at Mount Chiginagak is estimated to be similar in size (approximately $\left.10^{19}-10^{20} \mathrm{cal}\right)$ to that calculated for Aniakchak Crater (Smith and Shaw, 1979), located just $8 \mathrm{~km}$ south of the study-area boundary. Ukinrek Maars, which erupted in 1977, may represent an additional geothermal resource.

Oil and gas resources in the study area are probably small. Twelve dry holes have been drilled in the study area. The tract to the west (E1), which consists mainly of Tertiary nonmarine sedimentary and volcaniclastic rocks, has been evaluated based on the drilling. Analysis of the rocks for hydrocarbons indicates that they are immature, with an organic-carbon content of less than 2 percent (McLean, 1977). Tract E2, located on the east side of the study area, is largely a Mesozoic sedimentary province. Although this area has several small oil seeps located along the crest of two large anticlines, analysis of the rocks indicates poor reservoir characteristics for most of the Mesozoic section. Furthermore, the organic-carbon content of the Mesozoic rocks is low. Of the 12 dry holes in the study area, eight have been drilled near the surface oil seeps on the crests of these two anticlines.
Coal beds are present in the Tolstoi Formation near the southern boundary of the study area. Field data indicate that the grade ranges from subbituminous to anthracite near the contact with small intrusive bodies. One tract (A5) contains several beds 1 to $2 \mathrm{~m}$ in thickness that have been seen in traverses made at $5-\mathrm{km}$ spacings. If these beds are continuous, they could $\mathrm{l}$ ave economic potential.

\section{BULLETINS}

\section{Stratigraphic Clarification of the Shelikof Formation, Alaska Penins'lla}

(Excerpts from Bulletin 1537-A byW.H. Allaway, Jr., R.L. Detterman, J.W. Miller, and L.B. Magoon)

Field investigations during the course of this AMRAP investigation determined that the contact between the Shelikof Formation and the underlying Kialagvik Formation had been placed based on faunal zones rather than on lithostratigraphic units. This report redefines the contact between the two formations.

Capps (1923, p. C97-C98) defined the Shelikof Formation (Middle Jurassic) on the Alaska Peninsula but did not establish a type locality. He divided the formation into three members: a lower shale (siltstone) member, a middle sandstone member with conglomerate, and an upper shale (siltstone) member. Rapid facies changes make these members impractical for mapping. Capps placed the lower contact at the base of a conglomerate bed that occurs at the base of the lower siltstone member at Puale Bay. This conglomerte does not persist laterally, and as a result other workers have mapped the contact based on the change in fauna between the Bajocian and Callovian Stages (Middle Jurassic).

Smith (1925) proposed to place the contact at the base of the lowermost massive sandstone bed. This is the most easily mapped unit and is herein defined as the base of the Shelikof Formation. The type sectior is defined as along the northeast shore of Puale Bay, between the southern half of sec. 9, T. 28 S., R. 38 W. and sec. 19, T. 28 S., R. 37 W. in the Karluk C-4, C-5, and D-5 15-minute quadrangles.

\section{Petrography, Chemistry, and Geologic History of Yantarni Volcano, Aleutian Volcanic Arc, Alaska}

(Excerpts from Bulletin 1761 by J.R. Riehle, M.E. Yount, and T.P. Miller)

In 1979, during the course of this AJ IRAP study, R.L. Detterman and J.E. Case discovered a previously unknown Quaternary volcano near the south boundary of 
the map area, subsequently named Yantarni after the nearby bay of the same name. Yantarni volcano and neighboring Mounts Chiginagak and Kialagvik are located along the axis of the Wide Bay-Bear Creek anticline and the high-angle fault that extends southwest from the anticline; together, the three form a short segment of the Aleutian volcanic arc along which the volcanoes are approximately $35 \mathrm{~km}$ closer to the Aleutian Trench than those on either side. The Mike prospect, a locus of late Tertiary volcanism, is $5 \mathrm{~km}$ north of Yantarni dome.

Volcanic activity at Yantarni began in middle Pleistocene time with the eruption of andesite flows that now cap ridges to the west and south of the present summit. A catastrophic Holocene eruption (possibly 3,500 to 2,000 years ago; Riehle and others, 1987) breached the small, late Pleistocene stratocone, produced the present dome, and filled the valley to the east with approximately $1 \mathrm{~km}^{3}$ of pyroclastic flow deposits.

Yantarni volcanic rocks are calc-alkaline and range from 55 to 65 percent $\mathrm{SiO}_{2}$ (volatile free). Comparison of whole-rock chemistry and phenocryst chemistry suggests that small batches of magma feeding the volcanic system have occasionally intercepted one another beneath the volcano and mixed to form hybrid magmas (Riehle and others, 1987).

Although there is no historical record of activity at Yantarni, the possibility of future eruptions cannot be discounted.

\section{Interpretation of Exploration Geochemical Data From the Ugashik, Bristol Bay, and Western Karluk Quadrangles, Alaska}

\section{(Excerpts from Bulletin 1858 by S.E. Church, J.G. Frisken, and F.H. Wilson)}

The integration of the geochemical results from the geochemical maps (MF-1539-C, -F, -G, -H) are presented in an interpretative report in U.S. Geological Survey Bulletin 1858. Both drainage-basin analysis and factor analysis of the entire data sets are covered, and conclusions are drawn regarding the type of mineralization present.

Analysis of the geochemical data obtained from exploration geochemical studies has helped to define the limits of several porphyry $\mathrm{Cu}-\mathrm{Mo}$ target areas, some of which were previously unknown. Widespread geochemical anomalies and hydrothermal alteration halos are associated with an inferred Oligocene to Pliocene intrusive complex in the southern part of the Ugashik-Karluk study area. Two of these areas are the Rex prospect, a porphyry $\mathrm{Cu}$-Mo system associated with composite Oligocene intrusive rocks, and the Mike prospect, a porphyry Mo system associated with Pliocene intrusive activity. Both areas are outlined by $\mathrm{Cu}-\mathrm{Mo}-\mathrm{W}$ anomalies surrounding drainage basins that show base- and precious- metal anomalies. Aeromagnetic data suggest that there are several buried plutons in the area beneath the geochemical anomalies of the Mike prospect (Case and others, 1988). Further examination of several of these areas may be warranted.

Additional evidence of mineralization is associated with an area at Cape Igvak that shows possible hydrothermal vein or skarn mineralization, possibly assnciated with a pluton of Pliocene age. Gold, antimony, lead, and molybdenum mineralization at Cape Kubugakli appears to be restricted to quartz veins within the outcrop pattern of intrusive rocks. The intrusive rocks appear, from the aeromagnetic anomaly, to extend offshore to the east.

\section{REFERENCES}

The asterisks $\left({ }^{*}\right)$ denote references cited in this report. Plus signs $(+)$ indicate uncited references that mainly or entirely pertain to the Ugashik, Bristol Bay, and w'estern part of Karluk quadrangles. Unmarked referen-es are uncited general, regional, or topical in scope but contain material relevant to the quadrangles.

+Albert, N.R.D., 1982, Preliminary photogeologic interpretation map of side-looking airborne radar imagery of Bristol Bay, Ugashik, and Karluk quadrangles, Alaska: U.S. Geological Survey Open-File Report 82-141, scale $1: 250,000,2$ sheets.

*Allaway, W.H., Jr., 1982, Sedimentology and petrolozy of the Shelikof Formation, Alaska Peninsula: San Jose, Calif., San Jose State University, M.S. thesis, 88 p.

*Allaway, W.H., Jr., Detterman, R.L., Miller, J.W., and Magoon, L.B., 1984, Stratigraphic clarification of the Shelikof Formation, Alaska Peninsula, in Stratigraphic notes, 1983: U.S. Geological Survey Bulletin 1537-A, p. A21-A27.

*Allaway, W.H., Jr., and Miller, J.W., 1984, Newly rerognized sedimentary environments in the Shelikof Fcrmation, Alaska, in Coonrad, W.H., and Elliot, R.L., e.ds., The United States Geological Survey in Alaska: Accomplishments during 1981: U.S. Geological Survey Circular 868, p. 34-37.

Andreason, G.E., Dempsey, W.J., and Vargo, J.L., 1963a, Aeromagnetic map of part of the Naknek quadrangle, Alaska: U.S. Geological Survey Geophysical Investigation Map GP-353, scale 1:125,000.

1963b, Aeromagnetic map of parts of Ugashik and Karluk quadrangles, Alaska: U.S. Geological Survey Geophysical Investigation Map GP-354, scale 1:125,000.

Atwood, W.W., 1911, Geology and mineral resource: of parts of the Alaska Peninsula: U.S. Geological Surve"r Bulletin $467,137 \mathrm{p}$.

Barnes, D.F., 1967, Four preliminary gravity maps of parts of Alaska: U.S. Geological Survey Open-File Report, [67-10], 5 p.

-1977 a, Bouguer gravity map of Alaska: U.S. Geological Survey Geophysical Investigations Map GP-@13, scale $1: 2,500,000$. 
* __ 1979b, Gravity map of the western part of southern Alaska: U.S. Geological Survey Open-File Report 77169-H, scale 1:1,000,000.

*Barnes, Ivan, and McCoy, G.A., 1979, Possible role of mantlederived $\mathrm{CO}_{2}$ in causing two phreatic explosions in Alaska: Geology, v. 7, no. 9, p. 434-435.

Beikman, H.M., 1975, Preliminary geologic map of Alaska Peninsula and Aleutian Islands: U.S. Geological Survey Miscellaneous Field Studies Map MF-674, scale $1: 1,000,000,2$ sheets.

*Berg, H.C., and Cobb, E.H., 1967, Metalliferous lode deposits of Alaska: U.S. Geological Survey Bulletin 1246, 254 p.

*Blasko, D.P., 1976, Oil and gas seeps in Alaska, Alaska Peninsula, western Gulf of Alaska: U.S. Bureau of Mines Report of Investigations RI 8122, 78 p.

*Brockway, R.G., Alexander, Bryan, Day, Paul, Lyle, W.M., Hiles, R.M., Jr., Decker, William, Polski, William, and Reed, B.L., 1975, Bristol Bay region, stratigraphic correlation section, southwest Alaska: Anchorage, Alaska, The Alaska Geologic Society.

Bruns, T.R., and von Huene, Roland, 1977, Sedimentary basins of the Shumagin Shelf, western Gulf of Alaska: Proceedings, Offshore Technology Conference, 9th Annual Conference, Houston, Texas, May 2-5, 1977, p. 41-50.

*Burk, C.A., 1965, Geology of the Alaska Peninsula-island arc and continental margin: Geological Society of America Memoir 99, 250 p.

*Capps, S.R., 1923, The Cold Bay District, in Brooks, A.H., ed., Mineral resources of Alaska: U.S. Geological Survey Bulletin 739-C, p. C77-C117.

1934, Notes on the geology of the Alaska Peninsula and Aleutian Islands: U.S. Geological Survey Bulletin 857D, p. D141-D153.

*Case, J.E., Cox, D.P., Detra, D.E., Detterman, R.L., and Wilson, F.H., 1981, Maps showing aeromagnetic surveys and interpretation of the Chignik and Sutwik Island quadrangles, Alaska: U.S. Geological Survey Miscellaneous Field Studies Map MF-1053-B, scale 1:250,000, 2 sheets.

*Case, J.E., Detterman, R.L., Wilson, F.H., Chuchel, B.A., and Yount, M.E., 1988, Maps showing aeromagnetic survey and geologic interpretation of the Ugashik and part of Karluk quadrangles, Alaska: U.S. Geological Survey Miscellaneous Field Studies Map MF-1539-D, scale $1: 250,000,2$ sheets.

*Church, S.E., Detterman, R.L., and Wilson, F.H., 1989a, Mineral and energy resource assessment of the Ugashik, Bristol Bay, and western Karluk quadrangles, Alaska: U.S. Geological Survey Miscellaneous Field Studies Map MF-1539-I, scale 1:250,000.

*Church, S.E., Frisken, J.G., Detra, D.E., and Wilson, W.R., 1988 , Geochemical maps showing distribution of selected elements in stream sediments from the Ugashik, Bristol Bay, and western Karluk quadrangles, Alaska: U.S. Geological Survey Miscellaneous Field Studies Map MF-1539-F, scale 1:250,000.

*Church, S.E., Frisken, J.G., and Wilson, F.H., 1989b, Interpretation of exploration geochemical data from Ugashik, Bristol Bay, and western Karluk quadrangles, Alaska: U.S. Geological Survey Bulletin 1858, 45 p.

Coats, R.P., 1950, Volcanic activity in the Aleutian arc: U.S.
Geological Survey Bulletin 974-B, p. B35-B49.

Cobb, E.H., 1972a, Metallic mineral resources map of the Bristol Bay quadrangle, Alaska: U.S. Geological Survey Miscellaneous Field Studies Map MF-456, scale 1:250,000.

$-1972 \mathrm{~b}$, Metallic mineral resources map of the Karluk quadrangle, Alaska: U.S. Geological Survey Miscellaneous Field Studies Map MF-459, scale 1:250,000.

*Coe, R.S., Globerman, B.R., Plumley, P.W.. and Thrupp, G.A., 1985, Paleomagnetic results from Alaska and their tectonic implications, in Howell, D.G., ed., Tectonostratigraphic terranes of the circum-Pacific region: CircumPacific Council for Energy and Mineral Rerources, Earth Science Series No. 1, p. 85-108.

Cox, D.P., Detra, D.E., and Detterman, R.L., 1981, Mineral resources of the Chignik and Sutwik Islan 1 quadrangles, Alaska: U.S. Geological Survey Miscellaneous Field Studies Map MF-1053-K, scale, 1:250,000, 2 sheets.

*Cox, D.P., and Singer, D.A., eds., 1986, Mineral deposit models: U.S. Geological Survey Bulletin 1693, 379 p.

*Dall, W.H., 1896, Report of coal and lignite of Alaska: U.S. Geological Survey 17 th Annual Report, pt. 1, p. 763908.

*Dall, W.H., and Harris, G.D., 1892, Corre'ation papers: Neogene: U.S. Geological Survey Bulletir 84, 349 p.

+Detra, D.E., 1980, AMRAP geochemistry, Bristol Bay, Ugashik, and Karluk quadrangles, Alaska, in Reed, K.M., ed., U.S. Geological Survey in Alarka 1980 programs: U.S. Geological Survey Circular 823A, p. A52.

+Detra, D.E., Detterman, R.L., Cox, D.P., and Wilson, F.H., 1982, Reconnaissance geochemical stud: $\mathrm{s}$ in Bristol Bay, Ugashik, and Karluk quadrangles, Alaska, in Coonrad, W.L., ed., The United States Geological Survey in Alaska: Accomplishments during 1980: U.S. Geological Survey Circular 844, p. 87-88.

*Detra, D.E., Risoli, D.A., O'Leary, R.M., Hurrell, J.T., and Everman, W.E., 1981, Analytical data and statistical summary from analysis of stream-sediment and heavymineral-concentrate samples collected ir Bristol Bay, Ugashik, and Karluk quadrangles, Alaska: U.S. Geological Survey Open-File Report 81-963, 88 p.

Detterman, R.L., 1985, The Alaska Peninsula A-2 transect, in von Huene, Roland, ed., Continent-oceans transect A-2: Kodiak to Kuskokwin, Alaska: Geological Society of America Transect Series Map A-2, scale 1:500,000.

*Detterman, R.L., Allaway, W.H., Jr., Day, G.W., Hopkins, D.M., O'Leary, R.M., and Svec, Edward, 1982, Locality map for scintillometer and analytical data collected in 1981, Ugashik and Karluk quadrangles, Alaska: U.S. Geological Survey Open-File Report 82-53, scale 1:250,000, 1 sheet.

*Detterman, R.L., Allaway, W.H., Jr., O'Leary, F.M., Gruzensky, A.L., Hurrell, J.T., and Risoli, D.A., 1980, Sample location map and analytical data for rock samples collected in 1979, Ugashik and Karluk quadrangles, Alaska: U.S. Geological Survey Open-File Report 80-142, scale 1:250,000.

+ Detterman, R.L., Allaway, W.H., Jr., O'Leary, R.M., Houston, David, and Risoli, D.A., 1981a, Sample location map and analytical data for rock samples collected in 1980, Ugashik and Karluk quadrangles, Alaska: U.S. 
Geological Survey Open-File Report 81-173.

*Detterman, R.L., Allaway, W.H., Jr., and Rossiter, R.H., 1981b, Locality map and scintillometer data for the Ugashik and Karluk quadrangles, Alaska: U.S. Geological Survey Open-File Report 81-253, scale 1:250,000, 1 sheet.

*Detterman, R.L., Case, J.E., Wilson, F.H., and Yount, M.E., 1987a, Geologic map of the Ugashik, Bristol Bay, and western part of Karluk quadrangles, Alaska: U.S. Geological Survey Miscellaneous Geologic Investigations Map I-1685, scale 1:250,000, 1 sheet.

*Detterman, R.L., Case, J.E., Wilson, F.H., Yount, M.E., and Allaway, W.H., Jr., 1983, Generalized geologic map of the Ugashik, Bristol Bay, and part of Karluk quadrangles, Alaska: U.S. Geological Survey Miscellaneous Field Studies Map MF-1539-A, scale 1:250,000.

Detterman, R.L., and Miller, J.W., 1984, Late Mesozoic paleobiogeography and tectonics of the Alaska Peninsula [abs.]: Geological Society of America Abstracts with Programs, v. 16, no. 5, p. 278.

*Detterman, R.L., Miller, J.W., and Case J.E., 1985, Megafossi] locality map, checklists, and pre-Quaternary stratigraphic sections of Ugashik, Bristol Bay, and part of Karluk quadrangles, Alaska: U.S. Geological Survey Miscellaneous Field Studies Map MF-1539-B, scale 1:250,000, 3 sheets.

*Detterman, R.L., Wilson, F.H., Yount, M.E., and Miller, T.P., $1987 b$, Quaternary geologic map of the Ugashik, Bristol Bay, and western part of Karluk quadrangles, Alaska: U.S. Geological Survey Miscellaneous Geologic Investigations Map I-1801, scale 1:250,000, 1 sheet.

Detterman, R.L., Yount, M.E., and Case, J.E., 1981c, Megafossil locality map, checklists, and stratigraphic sections of the Chignik and Sutwik Island quadrangles, Alaska: U.S. Geological Survey Miscellaneous FieldStudies Map MF-1053-N, 2 sheets.

Dumond, D.E., 1980, The archaeology of Alaska and the peopling of America: Science, v. 209, no. 4460, p. 984-991.

Ferrians, O.J., Jr., 1965, Permafrost map of Alaska: U.S. Geological Survey Miscellaneous. Geologic Investigations Map I-445, scale 1:250,000.

Fisher, M.A., Bruns, T.R., and von Huene, Roland, 1981, Transverse tectonic boundaries near Kodiak Island, Alaska: Geological Society of America Bulletin, v. 92, no. 1 , pt. 1 , p. $10-18$.

*Frisken, J.G., Church, S.E., Detra, D.E., and Wilson, W.R., 1988a, Geochemical map showing the distribution of selected elements determined in nonmagnetic heavymineral concentrates from Ugashik, Bristol Bay, and western Karluk quadrangles, Alaska: U.S. Geological Survey Miscellaneous Field Studies Map MF-1539-G, scale 1:250,000.

*Frisken, J.G., Church, S.E., and Wilson, W.R., 1988b, Mineralogical map showing the distribution of selected orerelated mineral concentrates from Ugashik, Bristol Bay, and western Karluk quadrangles, Alaska: U.S. Geological Survey Miscellaneous Field Studies Map MF-1539$\mathrm{H}$, scale 1:250,000.

*Grimes, D.J., and Marranzino, A.P., 1968, Direct-current arc and alternating-current spark emission spectrographic field methods for the semiquantative analysis of geologic materials: U.S. Geological Survey Circular 591, 6 p.

+Hanson, B.M., 1957, Middle Permian limestone on Pacific side of Alaska Peninsula: American Association of Petroleum Geologists Bulletin, v. 41, no. 10, p. 2376-2378.

Imlay, R.W., 1953, Callovian (Jurassic) ammonites from United States and Alaska, Part 2, Alaska Peninsula and Cook Inlet regions: U.S. Geological Survey Professional Paper 249-B, p. B41-B108.

1975, Stratigraphic distribution and zonation of Jurassic (Callovian) ammonites in southern Alaska: U.S. Geological Survey Professional Paper 836, 28 p.

*___1980, Jurassic paleogeography of the conte minous United States in its continental setting: U.S. Geological Survey Professional Paper 1062, 134 p.

1981, Early Jurassic ammonites from Alaska: U.S. Geological Survey Professional Paper 1148, $49 \mathrm{p}$.

1984, Early and Middle Bajocian (Middle Jurassic) ammonites from southern Alaska: U.S. Geolog:cal Survey Professional Paper 1322, 38 p.

Imlay, R.W., and Detterman, R.L., 1973, Jurassic paleobiogeography of Alaska: U.S. Geological Survey Professional Paper 801, 34 p.

$+\longrightarrow$ 1977, Some Lower and Middle Jurassic beds in Puale Bay-Alinchak Bay area, Alaska: American Association of Petroleum Geologists Bulletin, v. 61 , no. 4, p. $607-$ 611.

Imlay, R.W., and Miller, D.J., 1949, Reconnaissance genlogy of Wide Bay, Puale Bay, and Chinitna Bay areas, southern Alaska: U.S. Geological Survey Administrative Report, $22 \mathrm{p}$.

Jones, D.L., and Miller, J.W., 1976, Preliminary geologic map of Alaska Peninsula showing post-Callovian Mesozoic fossil localities: U.S. Geological Survey Open-File Report 76-76, scale 1:500,000, 2 sheets.

*Jones, D.L., Silberling, N.J., and Hillhouse, J.W., 1978, Microplate tectonics of Alaska-Significance for Mesozoic history of the Pacific coast of North America, in Howell, D.G., and McDougall, K.A., eds., Mesozoic paleogeography of western United States: Society of Economic Paleontologists and Mineralogists Symposium, v. 8, p. 71-76.

Keller, A.S., and Reiser, H.N., 1959, Geology of the Mount Katmai area, Alaska: U.S. Geological Survey Bulletin 1058-G, p. G261-G298.

+ Kellum, L.B., Davies, S.N., and Swinney, C.M., 1945, Geology and oil possibilities of the southwestern part of the Wide Bay anticline, Alaska: U.S. Geological Survey C pen-File Report, 17 p.

*Kerr, R.A., 1987, Direct measurements confirm plat? tectonics: Science, v. 236 , no. 4807 , p. $1425-1427$.

+Kienle, Juergen, Kyle, P.R., Self, Stephen, Motyka, R.J., and Lorenz, Volker, 1980, Ukinrek Maars, Alaska; April 1977 eruption sequence, petrology, and tectonir setting: Journal of Volcanology and Geothermal Research, v. 7, no. 1-2, p. 11-37.

+Kover, A.N., and Martin, S.E., 1984, Ugashik, Alaska, sidelooking airborne radar (SLAR): U.S. Geological Survey Image Map Set, 8 sheets.

+ Le Compte, J.R., 1981, Preliminary map showing interpretation of Landsat imagery of the Ugashik and Karluk 
quadrangles, Alaska: U.S. Geological Survey Open-File Report 81-776, scale 1:250,000, 2 sheets.

* Martin, G.C., 1904, Petroleum fields of Alaska and the Bering River coal field: U.S. Geological Survey Bulletin 225, pp. 365-382.

* Alaska: U.S. Geological Survey Bulletin 250, 64 p.

*___ 1926, The Mesozoic stratigraphy of Alaska: U.S. Geological Survey Bulletin 776, 493 p.

${ }^{*}$ McLean, Hugh, 1977, Organic geochemistry, lithology, and paleontology of Tertiary and Mesozoic rocks from wells on the Alaska Peninsula: U.S. Geological Survey OpenFile Report 77-813, 63 p.

*Miller, J.W., and Detterman, R.L., 1985, The Buchia zones in Upper Jurassic rocks on the Alaska Peninsula, in Bartsch-Winkler, Susan, and Reed, K.M., eds., The United States Geological Survey in Alaska: Accomplishments during 1983: U.S. Geological Survey Circular 945, p. 51-53.

Miller, T.P., 1973, Distribution and chemical analyses of thermal springs in Alaska: U.S. Geological Survey Open-File Report 73-187, scale 1:250,000.

*Miller, T.P., and Smith, R.L., 1977, Spectacular mobility of ash flows around Aniakchak and Fisher Calderas, Alaska: Geology, v. 5, p. 173-176.

*___1987, Late Quaternary caldera-forming eruptions in the eastern Aleutian arc, Alaska: Geology, v. 15, p. 434-438.

Moore, G.W., 1967, Preliminary geologic map of Kodiak Island and vicinity, Alaska: U.S. Geological Survey Open-File Report 67-271, scale 1:250,000.

*Motooka, J.M., and Grimes, D.J., 1976, Analytical precision of one-sixth order semiquantitative spectrographic analysis: U.S. Geological Survey Circular 738, 25 p.

*Packer, D.R., and Stone, D.B., 1974, Paleomagnetism of Jurassic rocks from southwestern Alaska and their implications: Canadian Journal of Earth Sciences, v. 11, p. 976-997.

${ }^{*}$ Reed, B.L., and Lanphere, M.A., 1969, Age and chemistry of Mesozoic and Tertiary plutonic rocks in south-central Alaska: Geological Society of America Bulletin, v. 80, p. 23-43.

*__ 1972, Generalized geologic map of the Alaska-Aleutian Range batholith showing potassium-argon ages of the plutonic rocks: U.S. Geological Survey Miscellaneous Field Studies Map MF-372, scale 1,000,000, 2 sheets.

1973, Alaska-Aleutian Range batholith; geochronology, chemistry, and relation to circum-Pacific plutonism: Geological Society of America Bulletin, v. 84, p. 25832610.

*Riehle, J.R., Yount, M.E., and Miller, T.P., 1987, Petrography, chemistry, and geologic history of Yantarni volcano, Aleutian volcanic arc, Alaska: U.S. Geological Survey Bulletin 1761, 27 p.

+ Self, Stephen, Kienle, Juergen, and Huot, Jean Paul, 1980, Ukinrek Maars, Alaska; Deposits and formations of the 1977 craters: Journal of Volcanology and Geothermal Research, v. 7, no. 1-2, p. 39-65.

*Smith, R.L., and Shaw, H.R., 1979, Igneous related geothermal systems, in Muffler, L.J.P., ed., Assessment of geo- thermal resources of the United States, 1978: U.S. Geological Survey Circular 90, p. 12-17.

*Smith, W.R., 1925, The Cold Bay (Puale Bay)-Katmai district, in Brooks, A.H., ed., Mineral resources of Alaska: U.S. Geological Survey Bulletin 773-C, p. C183-C209.

* _-1926, Geology and oil development of the Cold Bay (Puale Bay) district, Alaska: U.S. Geslogical Survey Bulletin 783-C, p. C63-C95.

*Smith, W.R., and Baker, A.A., 1924, The Cold Bay (Puale Bay)-Chignik district, Alaska: U.S. Genlogical Survey Bulletin 755-D, p. D151-D218.

Stone, D.B., and Packer, D.R., 1977, Tectonic implications of Alaska Peninsula paleomagnetic data: Tectonophysics, v. 37, p. 183-201.

*Stone, D.B., and Packer, D.R., 1979, Paleomagnetic data from the Alaska Peninsula: Geological Society of America Bulletin, v. 90, pt. 1, p. 545-560.

Stone, D.B., Panuska, B.C., and Packer, D.R., 1982, Paleolatitudes versus time for southern Alaska: Journal of Geophysical Research, v. 87, no. B5, p. 369i-3707.

Thrupp, G.A., and Coe, R.S., 1984, Paleomagnetism of Tertiary volcanic rocks from Alaska Peninsula: Is the Peninsular terrane a coherent tectonic entity? [at:.]: Geological Society of America Abstracts with Programs, v. 16, no. 5, p. 337.

*United States Geological Survey, 1984, Aeromagnetic map of parts of the Ugashik and Karluk $1 \times 2$ degree quadrangles, Alaska: U.S. Geological Survey Open-File Report 84-351, scale 1:250,000, 2 sheets.

*Ward, F.N., Nakagawa, H.M., Van Sickle, G.H., and Harms, T.F., 1969, Atomic absorption methods of analysis useful in geochemical exploration: U.S. Geolog:cal Survey Bulletin $1289,45 \mathrm{p}$.

+Westerman, G.E.G., 1964, The ammonite fauna of the Kialagvik Formation at Wide Bay, Alaska Peninsula-Part 1, Lower Bajocian (Alenian): Ithaca, N. '. ., Paleontological Research Institution, v. 47, no. 216, p. 329-503.

$+\longrightarrow 1969$, The ammonite fauna of Kialagvir Formation at Wide Bay, Alaska Peninsula-Part 2, Sonninia sowerbyi zone (Bajocian): Ithaca, N.Y., Paleontological Research Institution, v. 57, no. 255, 226 p.

*Wilson, F.H., 1982, Map and tables showing preliminary results of K-Ar age studies in Ugashik quadrangle, Alaska Peninsula: U.S. Geological Survey Open-File Report 82-140, scalè 1:250,000.

*__ 1985, The Meshik Arc-an Eocene to earliest Miocene magmatic arc on the Alaska Peninsula: Alaska Division of Geological and Geophysical Surveys Professional Report 88, 14 p.

Wilson, F.H., Detterman, R.L., and Case, J.E., 1985, The Alaska Peninsula terrane: a definition: U.S. Geological Survey Open-File Report 85-450, 29 p.

*Wilson, F.H., Gaum, W.C., and Herzon, P.L., 1981, Map and tables showing geochronology and whole-rock geochemistry, Chignik and Sutwik Island quadrangles, Alaska: U.S. Geological Survey Miscellaneous Field Studies Map MF-1053-M, scale 1:250,000, 3 sheets.

*Wilson, F.H., and O'Leary, R.M., 1986, Maps and tables showing data and analysis of semiquantative emission spectrometry and atomic-absorption spectrometry of rock samples, Ugashik and western Karluk quadrangles, 
Alaska: U.S. Geological Survey Miscellaneous Field Studies Map MF-1539-C, scale 1:250,000.

*Wilson, F.H., and Shew, Nora, 1982, Preliminary results of $\mathrm{K}$-Ar age determinations from the Ugashik quadrangle, Alaska Peninsula, in Coonrad, W.L., ed., The United States Geological Survey in Alaska: Accomplishments during 1980: U.S. Geological Survey Circular 844, p. 86-87.
*__ 1988, Geochronology and major-element geochemistry of Ugashik, Bristol Bay, and western Karluk quadrangles, Alaska: U.S. Geological Survey Miscellaneorc Field Studies Map MF-1539-E, scale 1:250,000, 4 sheats.

Wolfe, J.A., 1972, An interpretation of Alaskan Tertiary floras, in Graham, A., ed., Floristics and paleofloristics of Asia and eastern North America: Amsterdam, Elserier, p. 201-233. 


\section{SELECTED SERIES OF U.S. GEOLOGICAL SURVEY PUBLICAT ONS}

\section{Perlodicals}

Earthquakes \& Volcanoes (issued bimonthly).

Preliminary Determination of Epicenters (issued monthly).

\section{Technical Books and Reports}

Professional Papers are mainly comprehensive scientific reports of wide and lasting interest and importance to professional scientists and engineers. Included are reports on the results of resource studies and of topographic, hydrologic, and geologic investigations. They also include collections of related papers addressing different aspects of a single scientific topic.

Bulletins contain significant data and interpretations that are of lasting scientific interest but are generally more limited in scope or geographic coverage than Professional Papers. They include the results of resource studies and of geologic and topographic investigations; as well as collections of short papers related to a specific topic.

Water-Supply Papers are comprehensive reports that present significant interpretive results of hydrologic investigations of wide interest to professional geologists, hydrologists, and engineers. The series covers investigations in all phases of hydrology, including hydrogeology, availability of water, quality of water, and use of water.

Circulars present administrative information or important scientific information of wide popular interest in a format designed for distribution at no cost to the public. Information is usually of short-term interest.

Water-Resources Investigations Reports are papers of an interpretive nature made available to the public outside the formal USGS publications series. Copies are reproduced on request unlike formal USGS publications, and they are also available for public inspection at depositories indicated in USGS catalogs.

Open-File Reports include unpublished manuscript reports, maps, and other material that are made available for public consultation at depositories. They are a nonpermanent form of publication that may be cited in other publications as sources of information.

\section{Maps}

Geologlc Quadrangle Maps are multicolor geologic maps on topographic bases in 7 1/2-or 15-minute quadrangle formats (scales mainly $1: 24,000$ or $1: 62,500$ ) showing bedrock, surficial, or engineering geology. Maps generally include brief texts; some maps include structure and columnar sections only.

Geophysical Investigations Maps are on topographic or planimetric bases at various scales; they show results of surveys using geophysical techniques, such as gravity, magnetic, seismic, or radioactivity, which reflect subsurface structures that are of economic or geologic significance. Many maps include correlations with the geology.

Miscellaneous Investigations Series Maps are on planimetric or topographic bases of regular and irregular areas at various scales; they present a wide variety of format and subject matter. The series also includes 7 1/2-mimute quadrangle photogeologic maps on planimetric bases which show geology as interpreted from aerial photographs. Series also includes maps of Mars and the Moon.
Coal Investigations Maps are geologic maps on topographic or planimetric bases at various scales showing bedrock or surficial geology, stratigraphy, and structural relations in certain coal-resource areas.

Oll and Gas Investigations Charts show stratigraphic information for certain oil and gas fields and other areas having pet"-leum potential.

Miscellaneous Field Studies Maps are multicolor or black-andwhite maps on topographic or planimetric bases on quadrangle or irregular areas at various scales. Pre-1971 maps show bedrock geology in relation to specific mining or mineral-deposit prol 'ems; post-1971 maps are primarily black-and-white maps on various subjects such as environmental studies or wilderness mineral investigetions.

Hydrologic Investigations Atlases are multicolored or black-andwhite maps on topographic or planimetric bases presenting a wide range of geohydrologic data of both regular and irregular areas; principal scale is $1: 24,000$ and regional studies are at 1:250,000 scalp or smaller.

\section{Catalogs}

Permanent catalogs, as well as some others, giving comprehensive listings of U.S. Geological Survey publications are available under the conditions indicated below from the U.S. Geological Survey, Books and Open-File Reports Section, Federal Center, Box 25425, Denver, CO 80225. (See latest Price and Availability List.)

"Publications of the Geologlcal Survey, 1879-1 19K1" may be purchased by mail and over the counter in paperback bonk form and as a set of microfiche.

"Publications of the Geological Survey, 1962- 1570" may be purchased by mail and over the counter in paperback book form and as a set of microfiche.

"Publications of the U.S. Geological Survey, 1971-1981" may be purchased by mail and over the counter in paperback book form (two volumes, publications listing and index) and as a set $\mathrm{c}^{\mathrm{f}}$ microfiche.

Supplements for 1982, 1983, 1984, 1985, 1986, art for subsequent years since the last permanent catalog may be purch rsed by mail and over the counter in paperback book form.

State catalogs, "List of U.S. Geological Survev Geologic and Water-Supply Reports and Maps For (State)," may be Futchased by mail and over the counter in paperback booklet form only.

"Price and Avallabillty List of U.S. Geological Survey Publications," issued annually, is available free of charge in paperback booklet form only.

Selected coples of a monthly catalog "New Publications of the U.S. Geological Survey" available free of charge by mail or may be obtained over the counter in paperback booklet form only. There wishing a free subscription to the monthly catalog "New Publicat'ons of the U.S. Geological Survey" should write to the U.S. Geologi ^al Survey, 582 National Center, Reston, VA 22092.

Note.--Prices of Government publications listed in older catalogs, announcements, and publications may be incorrect. Therefore, the prices charged may differ from the prices in catalogs, announcements, and publications. 